\title{
ACCOUNTING SUPPORT OF FINANCING IT-CLUSTERS ACTIVITY IN UKRAINE
}

\author{
Oleh Vysochan ${ }^{1}$, Vasyl Hyk ${ }^{2}$, Olha Vysochan ${ }^{3}$ \\ ${ }^{1}$ Doctor of Science in Economics, Professor, Lviv Polytechnic National University, \\ Bandery St. 12, Lviv, Ukraine. Phone Number+380973078178. E-mail: Oleh.S.Vysochan@lpnu.ua \\ ${ }^{2}$ Ph. D. in Economics, Associated Professor, Lviv Polytechnic National University, \\ Bandery St. 12, Lviv, Ukraine.Phone Number+380976129763.E-mail: Vasyl.V.Hyk@lpnu.ua \\ ${ }^{3}$ Ph. D. in Economics, Associated Professor, Lviv Polytechnic National University, \\ Bandery St. 12, Lviv, Ukraine. Phone Number+380973340787. E-mail: Olha.O.Vysochan@lpnu.ua
}

Received 2410202010 24; Accepted 14122020

In Ukraine, there is an independent model of financial capital formation of IT-clusters with a predominance in the structure of own sources (funds of its participants) and partial attraction of funds from various individuals and legal entities. However, in order to ensure expanded reproduction and effective functioning, it is necessary to diversify sources of funding, which can be carried out by attracting both budgetary and extrabudgetary funds. In the article the authors consider the current state and current issues of accounting for financial support of IT-clusters and outline the directions of their solution. Possible sources and forms of financing of IT-clusters and the system of displaying information on subaccounts of accounting are established. It is determined that for the accounting system of IT-clusters it is fundamental to divide other funds of targeted funding by purpose. For this purpose, we have proposed our own accounting approach, which provides for the preliminary creation of additional analytical sections for accounts that account for other funds of targeted funding: 4841 «Targeted financing of cluster activities» and 4842 «Targeted financing of cluster projects and programs».

Keywords: accounting, cluster, targeted funding, membership fees, venture funding, crowdfunding.

JET Codes: M41, O32.

\section{Introduction}

With the intensification of competition and the deepening globalization of the market space, such an innovative model of merging organizations as a cluster is becoming increasingly popular. As you know, in the modern sense, the latter is a rather complex social system that combines many components and is characterized by a large range of information and management and production and technological relationships. Accordingly, the successful operation of modern clusters requires the improvement of information and analytical system and a set of management levers, as well as the creation of an adequate legal framework that would clearly regulate the rules of the game (rules of conduct) and responsibility for non-compliance, effectively regulate contractual relations and determine control procedure. In Ukraine, despite some attempts in this direction, so far no qualitative, systematic, stable and consistent information support for the functioning of clusters has been formed, which would intensify the pace of their creation and development and at the same time help minimize the relevant transaction costs within these associations.

Copyright (C) 2020. Published by Vytautas Magnus University. This is an open access article distributed under the terms of the Creative Commons Attribution Non-Commercial 4.0 (CC BY-NC 4.0) license, which permits unrestricted use, distribution, and reproduction in any medium provided the original author and source are credited. The material cannot be used for commercial purposes 
One of the main reasons for this situation is insufficient justification at the theoretical level of financial conditions for adaptation of such new business associations as IT-clusters to the specific realities of the Ukrainian economy, which actualizes in-depth study of developments in cluster theory to outline the conceptual foundations rational organizational structure, as well as the formation of an effective financial mechanism for the operation of this association.

Cluster funding accounting is one of the most problematic areas, as it involves the use of a targeted funding account and earmarked revenue. Experience shows that the method of accounting for targeted funding of the cluster is considered insufficiently developed, and therefore there is a need to form it for further adaptation to accounting practice.

\section{Research analysis and problem formulation}

Problems of financial support of IT-clusters are of public interest among domestic and foreign scientists and are widely studied.

Kamenskikh (2018) emphasized the importance of network interaction in the context of economic and innovative development. Based on the theory of regional network interaction, the author created a theoretical and mathematical model that reflects the impact of cluster interaction on the level of financial and economic development. Increasing competitiveness through the use of cluster strategies was studied by Madiyarova, Łuniewski, Ibraeva (2019).

Scientific and methodological approach to the formation and use of financial capital of clusters on the basis of economic and mathematical modeling is presented in the work Busnyuk S.V. (2014). According to the author, the construction of a model for optimizing the formation of financial capital of the cluster should be preceded by the calculation and justification of its optimal structure.

Some authors studied the composition and structure of sources of funding for the cluster. Thus, Kropelnytska, Vusyatytska (2015) sources of funding for cluster development are divided into two groups: from public funds (state cluster assistance program) and private sources (participants' contributions, income from services, venture capital, mutual funds, sponsorship). Andreev (2018) notes that the sources of financial support for the development of smart clusters can be own, borrowed and involved resources. Strelnik (2020) made the most systematic list of available sources of funding for the cluster and its members, which must be taken into account in order to ensure the necessary cash flow. Alieksieiev, Mazur, Zhelizniak (2017) singled out the approach of using tax benefits for cluster members in order to stimulate innovation. It is proposed to form a STPP fund as a source of funding.

Burger, Baumöhl, Výrostová (2017) conducted a unique study of the funding structure of European and North American clusters. An independent survey collected data from 167 associations. In both regions, the share of public and private sources was approximately $43 \%$ and $57 \%$. European clusters are dominated by budget funds allocated from the European Union (24.29\%), and for American clusters the largest share was occupied by funding from the state $(26.25 \%)$ and local budgets $(10 \%)$.

Without underestimating the value of the work of the above-mentioned scientists, it should be recognized that the works present general management approaches, while the organization and methods of accounting for cluster financing are accompanied by certain problems, including insufficient regulation of current legislation and need improvement.

The purpose of the article is to identify the main problems of accounting for targeted funding of IT-clusters and develop recommendations for their solution for effective management. 


\section{Research methodology}

The study was conducted on the basis of the following scientific methods and techniques: a systematic approach - to assess the current state of financial support for IT-clusters; inductions and deductions - in the process of studying the general trends in the development of accounting for targeted financing of IT-clusters in Ukraine; theoretical comparison - to improve domestic approaches to accounting for targeted funding of IT- clusters based on international experience; methods of theoretical generalization and observation - to study the information support of the process of financing the activities of the IT cluster in Ukraine; method of comparative analysis - when allocating and dividing the target funding by purpose; abstract-logical, causal relations, concretization, formalization - to improve the accounting of sources of funding for IT-cluster.

\section{The research results}

Financial support should be considered as a system of all possible sources of economic growth of cluster structures. The main task of accounting for financial security should be to perform several functions - providing information on the process of formation of financial resources and their effective use. The main provisions of the formation of accounting and information support for cluster management are given in more detail in the works of the author (Hyk $(2018,2019))$.

The structure of costs for the formation and development of the cluster includes the costs of creating a cluster (ensuring organizational interactions, coordination, development and coordination of necessary documentation, etc.), costs of developing cluster infrastructure and maintaining its functioning and costs of implementing a specific cluster project. The characteristic feature of these investments is that their purpose is not to maximize profits, but to increase the value of the cluster structure through the creation and development of a competitive product.

Traditionally, in accounting, the composition of financial support includes own and borrowed funds, as well as budget funding. However, the list of sources of funding for cluster structures is somewhat broader, as it also includes non-budgetary or venture funding (Table 1).

Table 1. Characteristics and reflection in the accounting of sources of financing of the IT-cluster

\begin{tabular}{|l|l|l|}
\hline \multicolumn{1}{|c|}{ Source of funding } & \multicolumn{1}{c|}{ Form of financing } & \multicolumn{1}{c|}{ Display in the system of accounting accounts } \\
\hline Own funds & $\begin{array}{l}\text { Admission and } \\
\text { membership fees }\end{array}$ & $\begin{array}{l}\text { Subaccount 484 "Other funds of earmarked funding and } \\
\text { earmarked revenues» }\end{array}$ \\
\hline Raised funds & $\begin{array}{l}\text { Long- and short-term } \\
\text { bank loans }\end{array}$ & $\begin{array}{l}\text { Subaccount 501 "Long-term bank loans in national currency", } \\
601 \text { "Short-term bank loans in national currency" }\end{array}$ \\
\hline $\begin{array}{l}\text { Funds allocated from local } \\
\text { or state budgets }\end{array}$ & $\begin{array}{l}\text { Budget allocations, } \\
\text { grants }\end{array}$ & Subaccount 482 "Funds from the budget and state trust funds" \\
\hline $\begin{array}{l}\text { Non-budgetary or venture } \\
\text { financing }\end{array}$ & $\begin{array}{l}\text { Crowdfunding (public } \\
\text { funding) }\end{array}$ & $\begin{array}{l}\text { Subaccount 484 "Other funds of targeted funding and targeted } \\
\text { revenues» }\end{array}$ \\
\hline
\end{tabular}

Source: developed by the authors

At present, economic clusters in Ukraine are financed mainly by the own funds of their members (payment of mandatory entrance and membership fees). Admission fees are paid upon joining the organization, membership fees as a non-refundable monetary fee, which is periodically paid by a member of the association to ensure the current activities of the cluster. The amount and procedure for payment 
of fees are usually determined in internal regulations (for example, the Association "Lviv Cluster of Information Technologies and Business Services" (Lviv IT-cluster) has developed Regulations on membership fees).

To differentiate funding by type of membership fees Vysochan, Vysochan (2018) propose the opening of separate analytical accounts: 4841 "Basic (regular) membership fees" and 4842 "Additional membership fees", the use of which we consider possible also for cluster structures.

Attracting funds from commercial banks and other financial institutions to finance cluster initiatives is complicated by the fact that they provide project financing, ie it is assumed that investments will be directed to the project. The problem of attracting borrowed funds is due to the fact that the financing and implementation of an innovative cluster project starts from scratch, ie there is a high level of financial risk. Class 5 "Long-term liabilities" and 6 "Current liabilities" accounts are used to account for borrowings to finance clusters.

One of the important sources of funding for the cluster can be government revenues. However, it should be noted that adequate state financial support for cluster initiatives has not been observed in recent years. The solution to the problem is the introduction of systematic state support for clusters, which would allow them to fully use their potential for the development of the national economy.

To account for targeted funding of innovative projects from the state budget and other sources Kucherenko, Ratushna, Melnyk (2019) proposed to separate sub-accounts 485 Targeted financing of innovative projects from the budget» (state, regional, local) and 486 "Targeted financing of innovative projects at the expense of legal entities and individuals" (business angels, individuals participating in the crowdfunding platform, etc.). However, in our opinion, the introduction of additional sub-accounts is impractical, as they duplicate the functional purpose of sub-accounts 482 "Funds from the budget and state trust funds" and 484 "Other funds of targeted funding and targeted revenues".

In our opinion, the target revenues for state funding of cluster structures can be provided:

1) for the implementation of innovative projects. In this case, the targeted funding received is recognized as income in the period in which the costs associated with meeting the terms of the targeted funding are incurred. That is, the cluster receives the revenues provided by the budget target program with the requirement to use them for specific economic needs.

2 ) in the form of compensation of the interest rate on the attracted loan (financial support, by reducing the cost of loans). This type of state support may consist of compensation for interest accrued and paid in the current year for the use of loans. Typical postings and correspondence of accounts for public funding are given in table 2 .

Table 2. Correspondence of accounts on the account of the state financing

\begin{tabular}{|c|c|c|}
\hline The content of the business transaction & D-t & K-t \\
\hline \multicolumn{3}{|c|}{ Targeted funding for the implementation of innovative projects } \\
\hline Targeted funding was received from the budget to a special account & 313 & 482 \\
\hline Costs from targeted funding are reflected & 92 & $661,65,685$ \\
\hline Revenues from targeted financing in the amount of incurred expenses are reflected & 482 & 718 \\
\hline \multicolumn{3}{|l|}{ Targeted financing to compensate the interest rate on the loan } \\
\hline Received a short- or long-term bank loan & 311 & 501,601 \\
\hline \multirow[t]{2}{*}{ Accrued interest for using the loan is reflected and paid } & 951 & 684 \\
\hline & 684 & 311 \\
\hline Short-term or long-term bank loan repaid & 501,601 & 311 \\
\hline \multirow[t]{2}{*}{ The current account was reimbursed for the interest rate on the bank loan } & 311 & 482 \\
\hline & 482 & 718 \\
\hline
\end{tabular}

Source: developed by the authors 
One of the key tasks of the cluster is to intensify cooperation with venture companies to expand access to financial capital. However, the system of venture investment in Ukraine is in the process of formation. The main subjects of venture financing of cluster activities can be asset management companies (AMCs) and mutual investment institutions (CII), whose assets during 2010-2019 showed an upward trend (Fig. 1).

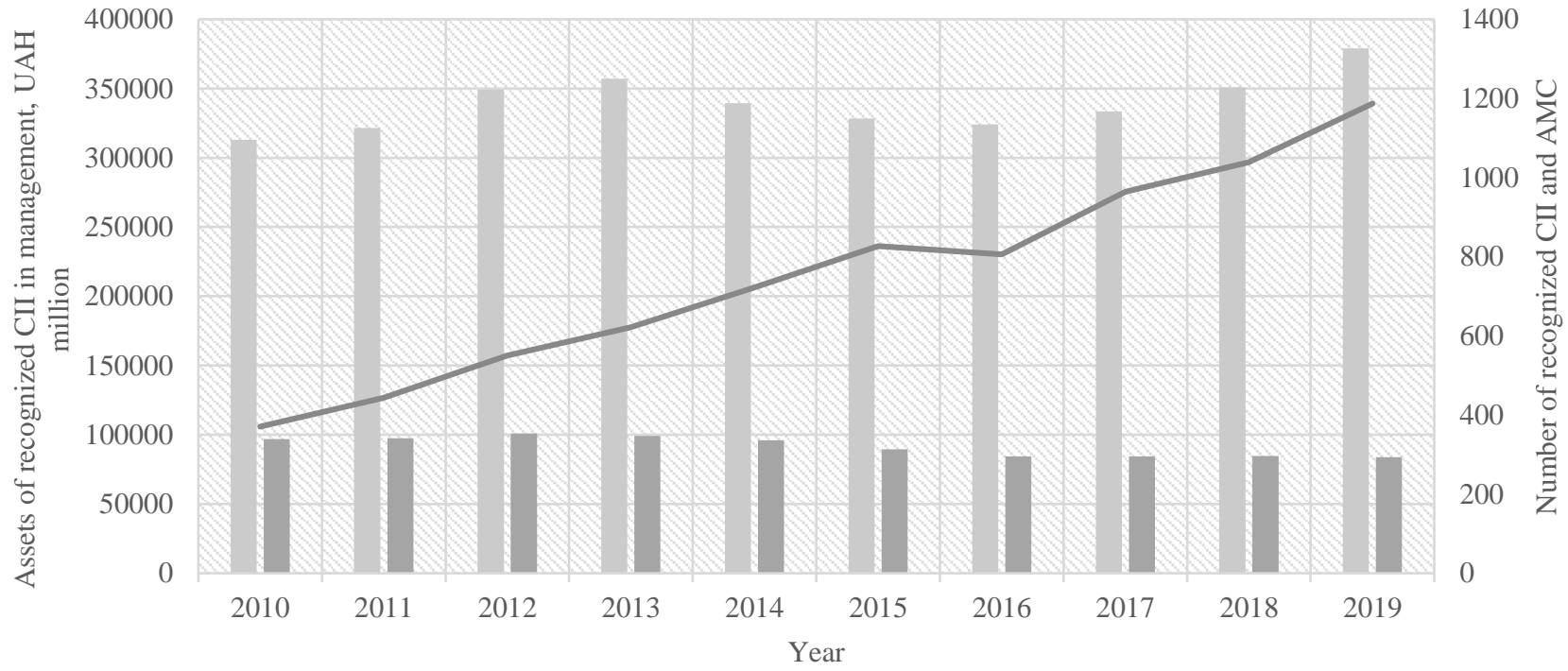

Number of recognized CII Number of AMC - Assets of recognized CII in management, UAH million

Figure 1. Dynamics of CII and AMC assets in Ukraine for 2010-2019

Source: built by the authors on the basis https://www.uaib.com.ua/analituaib/publ-iciquart?date=2019-12-31

Currently, there is no interest on the part of investors to invest in high-risk innovative projects, in contrast to foreign countries (Korea, Japan, China, Germany), where funds from the business sector, rather than the state, are the main sources of funding. A special feature of venture investment is its use in many countries around the world to directly finance innovative enterprises. When forming a cluster, the creation of an internal venture may be of special importance, the main task of which will be to finance innovative developments. Taking into account the fact that the structure of the cluster may include research institutions, the importance of venture financing of innovative development projects becomes more relevant.

Note that in practice there is no clear methodology for reflecting in the accounting of venture financing. Yakovets (2014) proposed to use sub-account 485 "Target financing in the framework of venture financing" with their details by stages of venture financing.

After analyzing the scientific literature, we offer our own accounting approach, which involves the preliminary creation of additional analytical sections on the accounts on which the accounting of other targeted funding (Table 3). 
Table 3. Fragment of the working plan of accounts for other funds of targeted funding

\begin{tabular}{|c|l|c|l|c|c|}
\hline \multicolumn{2}{|c|}{ First-order sub-account } & \multicolumn{2}{c|}{ Second-order sub-accounts } & \multicolumn{2}{c|}{ Third-order sub-accounts } \\
\hline Code & \multicolumn{1}{|c|}{ Name } & Code & \multicolumn{1}{c|}{ Name } & Code & \multicolumn{1}{c|}{ Name } \\
\hline 484 & $\begin{array}{l}\text { Other funds of targeted funding } \\
\text { and targeted revenues }\end{array}$ & 4841 & $\begin{array}{l}\text { Targeted financing of cluster } \\
\text { activities }\end{array}$ & 48411 & Membership fees \\
\cline { 2 - 6 } & 4842 & $\begin{array}{l}\text { Targeted financing of cluster } \\
\text { projects and programs }\end{array}$ & 48412 & Other contributions \\
\hline
\end{tabular}

Source: developed by the authors

For the accounting system of cluster structures, the division of other targeted funding by purpose is fundamental. In this regard, we propose to allocate sub-accounts: 4841'Targeted financing of cluster activities» and 4842 "Targeted financing of cluster projects and programs".

To obtain more detailed information on the targeted funding of the cluster, it is advisable, in our opinion, to use third-order sub-accounts: 48411 "Membership fees" (accounting for regular contributions from cluster members) and 48412 "Other contributions" (accounting for additional contributions, charitable donations, other funds of individuals and legal entities).

Typical postings and correspondence of accounts on the account of other means of target financing of cluster structures are given in table 4.

Table 4. Correspondence of accounts on accounting of accrual and receipt of other means of target financing

\begin{tabular}{|c|c|c|}
\hline The content of the business transaction & D-t & K-t \\
\hline \multicolumn{3}{|l|}{ Accrual and receipt of membership fees in full } \\
\hline Debts on accrued membership fees have been established & 377 & 48411 \\
\hline The receipt of contributions to the current account is reflected & 311 & 377 \\
\hline \multicolumn{3}{|l|}{ Accrual and receipt of membership fees received in advance } \\
\hline The receipt of membership fees to the current account is reflected & 311 & 69 \\
\hline Debts on accrued contributions have been established & 377 & 48411 \\
\hline Part of the debt on accrued contributions was written off & 69 & 377 \\
\hline \multicolumn{3}{|l|}{ Accrual and receipt of other contributions } \\
\hline The receipt of charitable funds on the current account is reflected & 311 & 48412 \\
\hline \multicolumn{3}{|l|}{ Write-off of received contributions } \\
\hline $\begin{array}{l}\text { Accrued income in the amount of incurred expenses that are related to the fulfillment of } \\
\text { the terms of use of contributions }\end{array}$ & $\begin{array}{r}48411, \\
48412 \\
\end{array}$ & 718 \\
\hline
\end{tabular}

Source: developed by the authors

The use of the proposed sub-accounts will create opportunities to obtain analytical data on other targeted funding and internal control over its rational use.

\section{Conclusions}

Thus, for the economic development of IT-clusters it is important to determine the most optimal structure of sources of funding for activities and projects (activities, programs). According to the results of the study, the main source of funding for the cluster is own and borrowed funds (charitable and other targeted assistance). The main purpose of the cluster is not to make a profit, so it is mandatory to use the proceeds solely to finance the costs of its maintenance, the realization of the purpose (goals, objectives) and activities defined by the constituent documents. 


\section{Management Theory and Studies for Rural Business and Infrastructure Development \\ eISSN 2345-0355. 2020. Vol. 42. No. 4: 497-503 \\ Article DOI: https://doi.org/10.15544/mts.2020.51}

Accounting for financial support should be considered as a kind of system of all possible sources of economic growth of the cluster. The key task of accounting for the financial support of cluster structures is to display information about the receipt (receipt) and use of own financial resources and attract the necessary amount of additional financial resources.

As a result of elaboration of scientific literature and practical experience, the authors revealed possible sources and forms of financing of IT-clusters and the system of displaying information on subaccounts of accounting. It is determined that for the purposes of accounting the classification of other means of target financing on purpose is fundamental. The authors formed and proposed an accounting version, according to which additional analytical sections are created for accounts on which other funds of targeted funding are recorded: 4841 «Targeted funding of cluster activities» and 4842 «Targeted funding of cluster projects and programs». The application of the proposals presented in the article will help to obtain an increased level of validity of management decisions on financing the activities of IT clusters and the possibility of implementing activities within the framework of sustainable development.

\section{References}

Alieksieiev, I.V., Mazur, A.V., Zhelizniak, R.Yo. (2017). The cluster of innovation activity tax incitement: formation and financing // Financial and credit activity: problems of theory and practice. Vol. 1. № 22. 328-335. https://doi.org/10.18371/fcaptp.v1i22.110048.

Andreev, M.A. (2018). Financial support for the development of intelligent clusters as a tool for implementing science-intensive technologies // Investments: practice and experience. № 20. 50-54. https://doi.org/10.32702/23066814.2018.20.50.

Burger, P., Baumöhl, E., Výrostová, E. (2017). Funding structure of the European and North American clusters: results from an independent questionnaire // Ekonomický časopis. 65. č. 6. 485-504.

Busnyuk, S.V. (2014). Formation of an optimal structure and cluster management system. Problems of economics and management. №1 (29). 17-23.

Hyk, V.V. (2018). Preconditions of forming accounting-information support of cluster management // Problems of theory and methodology of accounting, control and analysis. № 2 (40). 7-11. http://dx.doi.org/10.26642/pbo-2018-2(40)-711.

Hyk, V.V. (2019). Features of the cluster as an organization and system institute and their impact on the construction accounting // Problems of theory and methodology of accounting, control and analysis. №3 (44). 27-33. htps://doi.org/10.26642/pbo-2019-3(44)-27-33.

Kamenskikh, M. (2018). Assessment of cluster and network collaboration influence on regional economy // Journal of advanced research in law and economics. v. 9, n. 2. 510-515, https://doi.org/10.14505//jarle.v9 2(32).15.

Kropelnytska, S.O., Vusyatytska, M.P. (2015). Institutional and financial support for regional innovation development based on cluster approach // Economic Annals-XXI. 3-4(2). 37-40.

Kucherenko, T.Ye., Ratushna, O.P., Melnyk, L.Yu. (2019). Accounting for financing of the enterprise's innovation activities // Accounting and finance. № 1 (83). 35-43. https://doi.org/10.33146/2307-9878-2019-1(83)-35-43.

Madiyarova, D., Łuniewski, A., Ibraeva, A. (2019). Advancing competitiveness and developing the innovation and investment potential of industrial enterprises using cluster strategies // Journal of advanced research in law and economics. v. 10, n. 8. 2417-2428. https://doi.org/10.14505/jarle.v10.8(46).20.

Strelnik, M.M. (2020). Sources of funding for the cluster and its members // Bulletin of the Altai academy of economics and law. № 9. 155-165.

Vysochan, O.S., Vysochan, O.O. (2018). Features of accounting for political parties: the membership fees accounting // Accounting and finance. № 1 (79). 28-33.

Yakovets, H.Yu. (2014) Development of the venture financing mechanism in Ukraine: accounting and economic aspect // Problems of theory and methodology of accounting, control and analysis. № 3 (30). 459-465. 